\title{
Spatial patterns in sedimentary macrofaunal communities on the south coast of Newfoundland in relation to surface oceanography and sediment characteristics
}

\author{
Patricia A. Ramey ${ }^{1,2, *}$, Paul V. R. Snelgrove ${ }^{1,3}$ \\ ${ }^{1}$ Biology Department and Fisheries Conservation Chair, Memorial University of Newfoundland, St. John's, \\ Newfoundland A1C 5R3, Canada \\ ${ }^{2}$ Present address: Institute of Marine and Coastal Sciences, Rutgers University, 71 Dudley Road, \\ New Brunswick, New Jersey 08901-8521, USA \\ ${ }^{3}$ Present address: Canada Research Chair in Boreal and Cold Ocean Systems, Ocean Sciences Centre, \\ Memorial University of Newfoundland, St. John's, Newfoundland A1C 5S7, Canada
}

\begin{abstract}
This is the first comprehensive study of the community structure and spatial distribution of macrofauna in deep, muddy sediments of Placentia Bay, Newfoundland, and the adjacent shelf. The study examines the influence of water column (e.g. chlorophyll a [chl a], temperature and salinity) and sediment characteristics (e.g. grain size, carbon and nitrogen content) on infaunal patterns. Box-core samples were collected at 10 sites in June and July of 1998 from the head of the bay to the edge of the continental shelf. Multivariate analyses of community composition and environmental variation indicated inshore and offshore groupings. Inshore communities had lower species richness, diversity and densities. Fauna living deeper in the sediment were also more abundant in offshore areas. The inshore region was characterised by greater mixed-layer temperatures, higher surface $\mathrm{chl} a$ and large amounts of relatively fresh organic carbon (low $\mathrm{C} / \mathrm{N}$ ratios) in sediments. Within the inshore sites, high levels of organic carbon influenced macrofaunal assemblages that were similar to those characteristic of organic-rich areas. Surface chl a concentration was positively correlated with sedimentary organic carbon, which was the most important predictor of infaunal abundance. At broad scales, surface chl $a$ and sedimentary organic carbon were negatively related to infaunal abundance. Moreover, this pattern was confounded by particularly low densities at 3 inshore sites where organic levels were very high, and elevated densities at 1 productive offshore site. Low densities at these 3 inshore sites may be a result of sulphide production in sediments, or of poor food quality. Broad-scale patterns (inshore vs offshore) of community composition and abundance in Placentia Bay are largely influenced by surface oceanography through production export.
\end{abstract}

KEY WORDS: Benthic-pelagic coupling - Placentia Bay · Diversity · Benthic macrofauna · Continental shelf

Resale or republication not permitted without written consent of the publisher

\section{INTRODUCTION}

Marine benthic infaunal species are characteristically patchy in distribution, abundance and diversity (e.g. Volchaert 1987, Morrisey et al. 1992). This patchiness has been long recognised (Petersen 1913, Jones 1950) and a number of studies have shown that in- faunal species which define particular assemblages or communities are influenced by a variety of environmental and biological factors.

Longhurst (1998) divided the ocean into biogeographic regions based primarily on biophysical attributes of surface waters; these same variables that are so important in pelagic systems also influence bottom- 
living organisms. For example, temperature, salinity and depth often influence broad distributions (from $1 \mathrm{~km}$ to $1000 \mathrm{~s} \mathrm{~km}$ ) in terms of physiological constraints (e.g. Houston \& Haedrich 1984: depth). Circulation patterns can influence benthic communities in many ways. Most importantly, they modify other water column processes, such as near-bottom flow, that bring food and new recruits to the community (e.g. Butman 1987, Snelgrove \& Butman 1994). Moreover, bottom currents largely determine sediment type and food supply (i.e. organic content) to the benthos, which in turn influences benthic patterns (e.g. Gray 1974, Rhoads 1974). Circulation also affects larval supply to benthic habitats because larval supply is thought to be primarily passive over broad scales (Butman 1987, Bradbury \& Snelgrove 2001). However, the link between larval supply and benthic pattern is a subject of continuing debate (Ólafsson et al. 1994, Snelgrove \& Butman 1994). Circulation is closely linked to wind as well as topographic features such as islands and banks, which can create enhanced larval retention through eddies (Lobel \& Robinson 1986, Tremblay et al. 1994), and also produce highly productive areas associated with upwelling that may influence larval transport and survival (e.g. Shanks 1995). All of these processes act in concert with post-settlement processes such as disturbance (e.g. Rhoads \& Young 1970, Woodin 1978), predation (e.g. Peterson 1979) and competition (e.g. Peterson 1977) to influence benthic patterns in distribution and abundance.

Most soft-bottom communities at depths below the photic zone are dependent on sinking water column production as the major food source, and thus the quality and quantity of organic matter reaching the seabed is likely to be an important influence on benthic community structure, biomass and metabolism (Mills 1975, Jørgensen 1983, Smetacek 1984). Horizontal advection can complicate this linkage by causing a spatial discontinuity between surface waters and the benthos through transport of sinking particles (detritus, larvae) to a bottom area that is distant from the surface waters where they were abundant (e.g. Walsh et al. 1988, Lampitt et al. 1995). In addition, decoupling between herbivory and primary production can result in greater export of production to the bottom as a result of lowered zooplankton grazing rates (Ambrose \& Renaud 1995).

With the exception of pollution studies (e.g. Pearson et al. 1983), most benthic-pelagic coupling studies have examined infaunal response to organic matter input (i.e. phytodetritus) using community bulk measurements such as oxygen or carbon dioxide exchange (Smith et al. 1983, Duineveld et al. 2000, Witbaard et al. 2000), heat or nutrient release (Smith et al. 1983) or changes of bacterial biomass (ATP) (Drazen et al. 1998). Limited attention has been given to responses of specific infaunal groups or individuals to variable organic matter inputs. Studies of bacteria (Lochte \& Turley 1988, Pfannkuche 1993), meiofauna (Pfannkuche 1993, Gooday et al. 1996) or macrofauna (Long \& Lewis 1987, Grebmeier et al. 1988, Pfannkuche 1993, Ambrose \& Renaud 1995) have shown a variety of community responses to the input of organic matter.

Macrofaunal studies have typically found a positive relationship between benthic abundance and biomass and enhanced flux of organic carbon to the seabed (Elmgren 1978, Davies \& Payne 1984). For example, Grebmeier et al. (1988) found a significantly greater benthic biomass in the Bering Shelf region where water column primary production was much higher, and Ambrose \& Renaud (1995) found water column and benthic pigment (chlorophyll $a[\mathrm{chl} a]$ and phaeopigment) concentration were the most important predictors of infaunal density and polychaete biomass.

Although many factors influence patterns of species composition and diversity, it has proven difficult to determine which of these covariables are most important in creating and maintaining structure within benthic communities, particularly given the extreme patchiness of infauna (Whitlatch 1980). Spatial and temporal variability are a major feature of the pelagic realm and the linkage to benthic community pattern is not well understood, especially in cold ocean systems (Snelgrove et al. 2000).

Data on relatively broad-scale $(100 \mathrm{~s} \mathrm{~km})$ benthic structure as a function of oceanographic variables are few. The present work is part of a larger study on the Placentia Bay, Newfoundland, ecosystem (e.g. Lawson \& Rose 2000, Bradbury et al. 2000, Bradbury \& Snelgrove 2001), and the availability of complementary data on surface oceanography provides an opportunity to study benthic patterns of diversity and abundance in relation to a suite of relatively large-scale oceanographic variables. Although studies that have linked surface production to benthic biomass and abundance are typically at larger scales than the Placentia Bay study, multiple surveys of Placentia Bay indicate strong spatial variation in phytoplankton (Bradbury et al. 2000) and zooplankton communities (P. V. R. Snelgrove, S. Fraser, I. R. Bradbury unpubl. data).

The present study describes the community structure and spatial distribution of sedimentary macrofauna on muddy substrates in Placentia Bay and the adjacent shelf environment in relation to environmental variables. Specifically, water column characteristics, such as surface production chl $a$, and sedimentary characteristics, such as carbon and nitrogen content, are examined in order to determine how they influence infaunal community composition and diversity along an inshore/offshore gradient that extends from the head of Placentia Bay to the edge of the continental shelf. 


\section{MATERIALS AND METHODS}

Study site. Placentia Bay is a large embayment on the south coast of Newfoundland (Fig. 1), 132 km long (oriented NNE to SSW) and $100 \mathrm{~km}$ wide at its southern mouth, which links it to the adjacent shelf environment. Several shallow banks are interspersed with channels $>200 \mathrm{~m}$ in depth. The inner part of the bay is divided longitudinally into 3 channels by several islands, whereas the outer bay and shelf are wide open. Circulation patterns within the bay are characterised by northerly flow on the eastern side and southerly flow on the western side, with relatively weak flows at the head of the bay (see Bradbury et al. 2000, Schillinger et al. 2000). Oderin Bank, located in

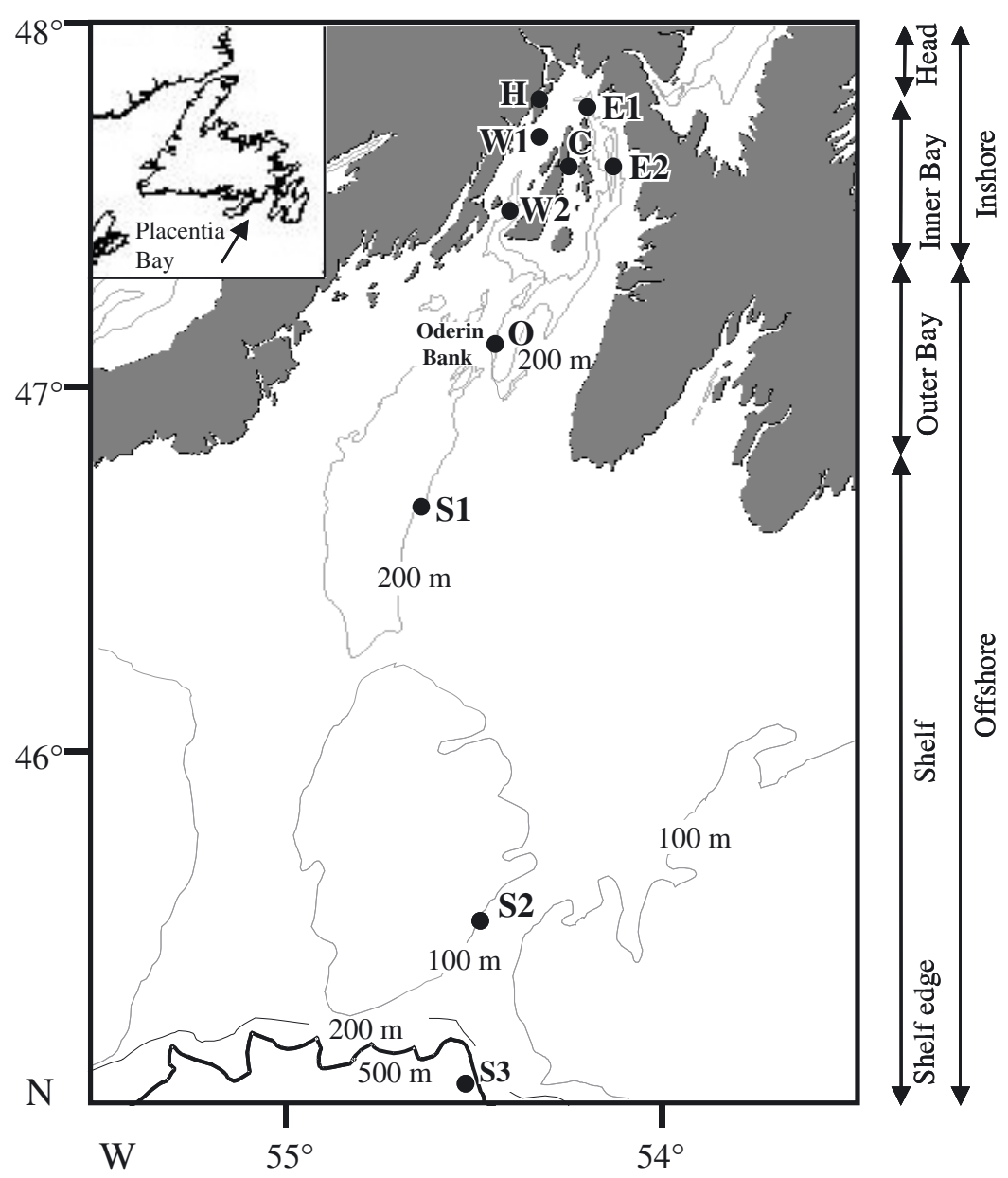

Fig. 1. Placentia Bay and sampling site locations. Capital letters indicate sampling sites. $\mathrm{H}$ denotes head of bay, $\mathrm{C}$ denotes Central Channel, $\mathrm{E}_{1}$ and $\mathrm{E}_{2}$ are upper and lower Eastern Channel, $\mathrm{W}_{1}$ and $\mathrm{W}_{2}$ are Western Channel, $\mathrm{O}$ is outer bay, $\mathrm{S}_{1}$ and $\mathrm{S}_{2}$ are shelf, and $\mathrm{S}_{3}$ is the shelf edge. Arrows on the right indicate different parts of the bay including the head and inner bay (collectively the inshore), and the outer bay and shelf (collectively offshore). Inset shows Placentia Bay in relation to Newfoundland. The $100 \mathrm{~m}$ depth contour is not shown for the inshore region because it is too close to the $200 \mathrm{~m}$ contour the outer bay, is known locally to be a productive area with summer upwelling.

Sampling design. Samples were collected with a small, rectangular single-spade box corer, containing 6 subcores that each measured $10 \times 10 \mathrm{~cm}$ wide and $30 \mathrm{~cm}$ deep. Replicate $600 \mathrm{~cm}^{2}$ box-core samples were collected using a random, nested design within each site, encompassing a geographic area of $1.4 \mathrm{~km}^{2}$. A total of 6 replicates were collected from sites in the inner bay; however, because of ship time constraints only 2 to 3 replicates were collected from each of the sites located between the outer bay and shelf edge (i.e. Sites $\mathrm{O}, \mathrm{S}_{1}, \mathrm{~S}_{2}, \mathrm{~S}_{3}$ ). In some instances, alternate sampling sites were randomly generated, using the same method described above, because bottom substrate at some of the initial sites was not appropriate for the sampling gear. Most samples were collected from similar depths with the average site depth ranging between 184 and $232 \mathrm{~m}$. However, a site at the head of the bay $(\mathrm{H})$ was much shallower $(\sim 67 \mathrm{~m})$ and another in the lower Western Channel $\left(\mathrm{W}_{2}\right)$ was deeper ( 286 m).

Infaunal sampling. The subdivision of the box corer into 6 subcores allowed several variables to be sampled simultaneously. Four of the subcores were processed over a $500 \mu \mathrm{m}$ screen to evaluate the macrofaunal community, and 1 of the 2 remaining subcores was used for $\mathrm{CHN}$ and grain size analyses. Because macrofauna generally occur within the top 6 to $8 \mathrm{~cm}$ of sediment and are usually concentrated in the welloxygenated top $3 \mathrm{~cm}$, subcores were sectioned into 0 to $3 \mathrm{~cm}$ and 3 to $10 \mathrm{~cm}$ vertical increments for macrofaunal analysis; this strategy facilitated later processing. Macrofaunal samples were initially preserved in $4 \%$ buffered formalin and then transferred to $70 \%$ ethanol with rose bengal. Only macrofaunal individuals were enumerated and identified to species where possible. Nemerteans and a few representatives from difficult groups such as Capitellidae and Paraonidae were not identified to the species level.

Environmental data. Vertical casts for salinity and temperature were collected with a Seabird 25 CTD concurrently with box core samples at 1 of the replicate sampling areas at each site within the inner bay, outer bay and shelf edge and at 2 of the replicate sampling areas at each site on the shelf $\left(\mathrm{S}_{1}\right.$ and $\mathrm{S}_{2}$ ). Mixed-layer temperatures and salinities were determined by averaging the upper 
$40 \mathrm{~m}$ from each profile, and bottom temperatures and salinities were taken from approximately $5 \mathrm{~m}$ above the bottom. Chl a samples were collected from a grid of stations throughout Placentia Bay during June and August 1998. Triplicate $100 \mathrm{ml}$ samples were collected with a 51 Niskin bottle at $5 \mathrm{~m}$ depth and analysed by methods outlined by Bradbury et al. (2000). These measurements were consistent with distributions observed in SeaWiFS (sea-viewing wide field of view sensor) sea surface images for the same time period (see http://dfomr.mar.dfo-mpo.gc.ca./science/ocean/ seawifs/seawifs_1.html). Chl a measurements for April, July and September were taken from SeaWiFS. Distances of each site from the nearest shoreline and from the head of the bay were determined using the program Mapinfo. CTD casts and chl a measurements were not conducted at all replicate sampling areas due to ship time constraints.

Sediment analyses. For grain size analysis, a 50:50 water:peroxide solution was added to each sediment sample and then heated to remove organics. Disaggregated samples were wet-sieved for coarse fractions (62.5 to $350 \mu \mathrm{m})$, whereas sedigraph analysis $(5100$ Micromeritics) was used to determine fine fractions $(<62.5 \mu \mathrm{m})$ (modified from Lewis \& McConchie 1994). For CHN analysis, samples were freeze-dried at $-60^{\circ} \mathrm{C}$ prior to analysis in a Perkin Elmer Model 2400. Sediments were not acid-treated prior to elemental analysis to remove inorganic carbon because shell fragments were not observed in sediments and sediment samples from other Newfoundland Bays have shown that carbonate concentrations are very low and do not affect total carbon values (E. Hatfield, Memorial University, pers. comm.).

Data analyses. The 4 subcores in a given boxcore were pooled for community composition analysis, resulting in 6 replicate samples $\left(400 \mathrm{~cm}^{2}\right.$ surface area each) at each site within the bay, but fewer replicates in the outer bay and shelf. Community composition was compared among sites using CNESS (chord distance normalised expected species shared) as described by Trueblood et al. (1994). CNESS is an extension of Orloci's (1978) chord distance and Grassle \& Smith's (1976) NESS (normalised expected species shared). This particular index was chosen because it is sensitive to rare as well as abundant species. Distribution patterns were clustered using unweighted, pair-group mean average sorting of CNESS dissimilarities (COMPAH 96, E. D. Gallagher, University of Massachusetts, Boston); a metric scaling of CNESS was also performed (Matlab program by E. D. Gallagher).

The normalised hypergeometric probability matrix (H) that was produced by metric scaling of CNESS was then analysed by principal components (PCA-H). Plots produced from this analysis are very similar to those produced by non-metric multidimensional scaling (NMDS) (Trueblood et al. 1994, Snelgrove et al. 2001); however, because the scaling is metric, it is possible to overlay a Gabriel Euclidean distance biplot (Gabriel 1971), where the length and angle of species vectors indicate the contribution of the species to the PCA-H axes. For simplicity, only species that contributed $>5 \%$ to CNESS variation were included in the biplots.

Determining which species are most influential in creating the spatial pattern from the biplots alone is somewhat subjective, because biplots capture withinsite as well as between-site variation. To provide a more objective interpretation, discriminant function analysis (SPSS 8.0) was also performed with site grouping (as determined from PCA-H analysis) designated as factor. This analysis was not used for formal hypothesis testing; instead it was used as a relative yardstick to evaluate which species were responsible for the between-site variation observed in the PCA-H plots. Taxa with a p-value $<0.05$ were designated as most important. The percentage that each species contributed to total individuals was calculated using the same site groupings as the discriminant function analysis.

PCA (principal component analysis) determined differences among the 10 sampling sites based on environmental variables, including abiotic and biotic water column variables and sediment-related measures (SPSS 8.0). Prior to analysis, variables were standardised $Z$-scores to weight all variables equally. Because of the close proximity of replicate sites, environmental variables were only collected for 1 or 2 of the replicate sampling locations at each site; replication of environmental variables was therefore less than it was for species data. Summary biotic variables (e.g. diversity) were linearly correlated with environmental variables; Dunn-Šidák adjustment of the p-value resulted in a critical p-value of 0.0002 . A multiple regression with adjusted $F$-ratios and p-values was also run separately with diversity, richness and density as the dependent variable and environmental variables as the independent variables. A stepwise approach was used, so only significant variables were included in the model. Given that many of the environmental variables in this study are interrelated, only 9 were used in this analysis: depth, \% organic carbon (variation in $\mathrm{C} / \mathrm{N}$ ratios among sites was small), mixed-layer temperature, bottom temperature, bottom salinity, mixed-layer salinity, distance from the head of the bay, chl $a$ in June and \% very fine to medium silt.

Summary variables (Shannon-Wiener diversity $H^{\prime}$ [base 2], richness, evenness and density of total macrofauna) were compared at each site by plotting means and $95 \%$ confidence intervals. Vertical fractions (i.e. total density in the 0 to $3 \mathrm{~cm}$ fraction compared to the 


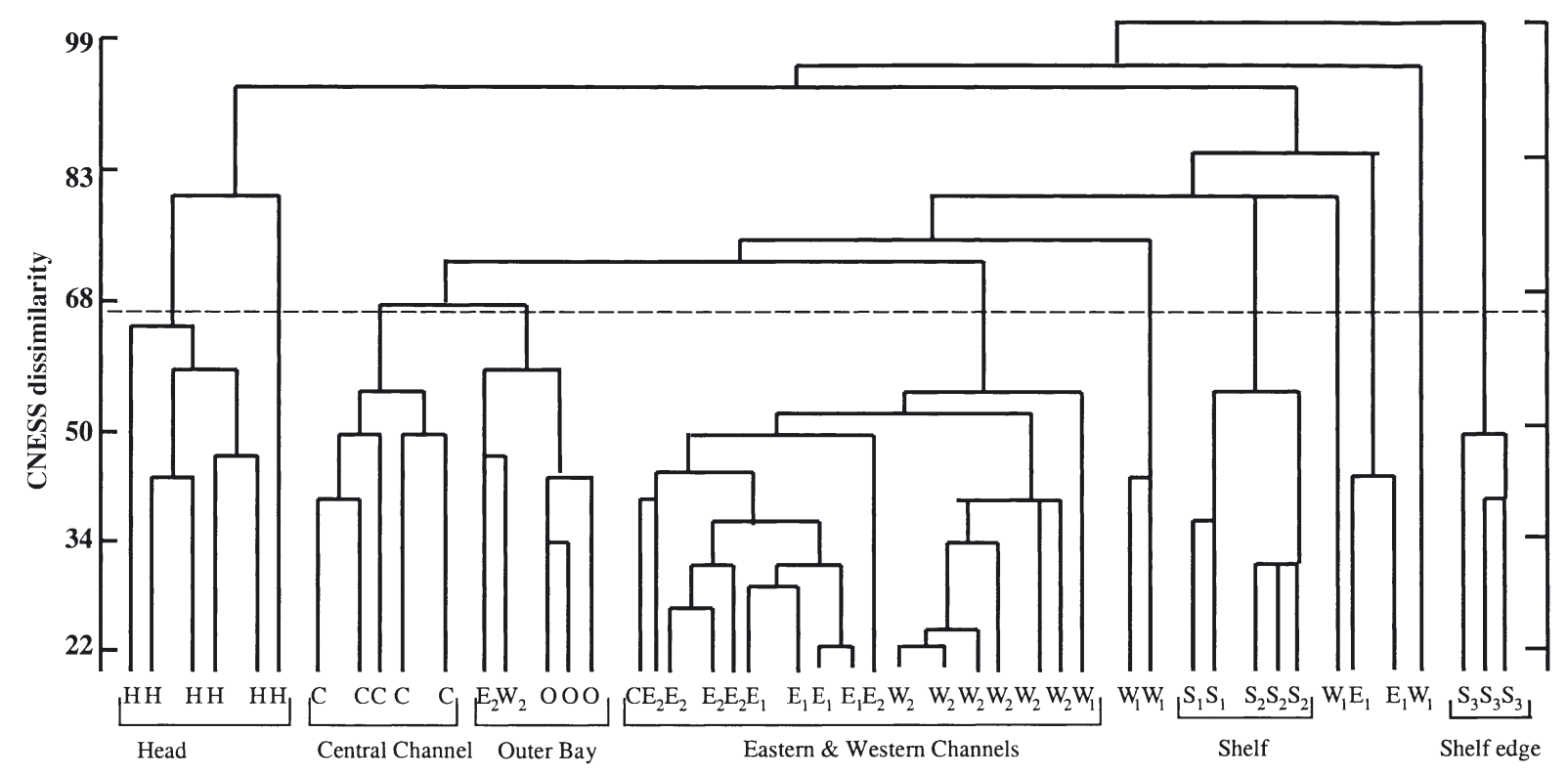

Fig. 2. Cluster analysis of the 10 site (47 box core samples) by 118 species matrix based on CNESS dissimilarity. Capital letters stand for sites sampled: $\mathrm{H}$ (head bay), $\mathrm{E}_{1}$ and $\mathrm{E}_{2}$ (upper and lower Eastern Channel), $\mathrm{W}_{1}$ and $\mathrm{W}_{2}$ (upper and lower Western Channel), $\mathrm{C}$ (Central Channel), $\mathrm{S}_{1}$ and $\mathrm{S}_{2}$ (shelf) and $\mathrm{S}_{3}$ (shelf edge)

3 to $10 \mathrm{~cm}$ fraction) were also compared among different areas of the bay to examine whether some sites contained deeper-living infauna compared to others. Average densities of the dominant taxa (i.e. taxa that were among the 4 most abundant at any 1 site) were compared by plotting means and 95\% confidence intervals for each site. Because multivariate analyses suggested an inshore/offshore difference, where the outer bay was more similar in terms of species composition and environmental variables to the shelf samples (see 'Results'), offshore and inshore samples were grouped separately for diversity comparisons. Inshore and offshore comparisons were made with a Mann-Whitney $U$-test.

\section{RESULTS}

At a dissimilarity of $67 \%$, cluster analysis showed 6 infaunal groups (Fig. 2): the head (H), Central Channel (C), outer bay $(\mathrm{O})$, combined Eastern and Western Channels $\left(E_{1 \& 2}\right.$ and $\left.W_{1 \& 2}\right)$, shelf sites $\left(S_{1}\right.$ and $\left.S_{2}\right)$ and shelf edge $\left(\mathrm{S}_{3}\right)$. Site groupings based on PCA-H analysis were less ambiguous (Fig. 3), with distinct communities at the head of the bay $(\mathrm{H})$, in the Central Channel (C) and at the edge of the continental shelf $\left(\mathrm{S}_{3}\right)$. The Eastern and Western Channels formed a grouping (except for several Western Channel samples), and the outer bay $(\mathrm{O})$ and shelf sites $\left(\mathrm{S}_{1}\right.$ and $\left.\mathrm{S}_{2}\right)$ formed another grouping. Thus, the inner bay channel samples $\left(\mathrm{E}_{1 \& 2}\right.$ and $\mathrm{W}_{1 \& 2}$ ) were generally similar to one another and the outer bay samples $(\mathrm{O})$ were more similar to those collected from the shelf $\left(\mathrm{S}_{1}, \mathrm{~S}_{2}\right)$. Moreover, unlike the pattern observed for the inner bay, the outer bay/shelf sites $\left(\mathrm{O}, \mathrm{S}_{1}, \mathrm{~S}_{2}\right)$ were distinct from one another, and the shelf edge site $\left(\mathrm{S}_{3}\right)$ was distinct from each of these. Thus, benthic composition changed and became more spatially distinct with increased distance from the

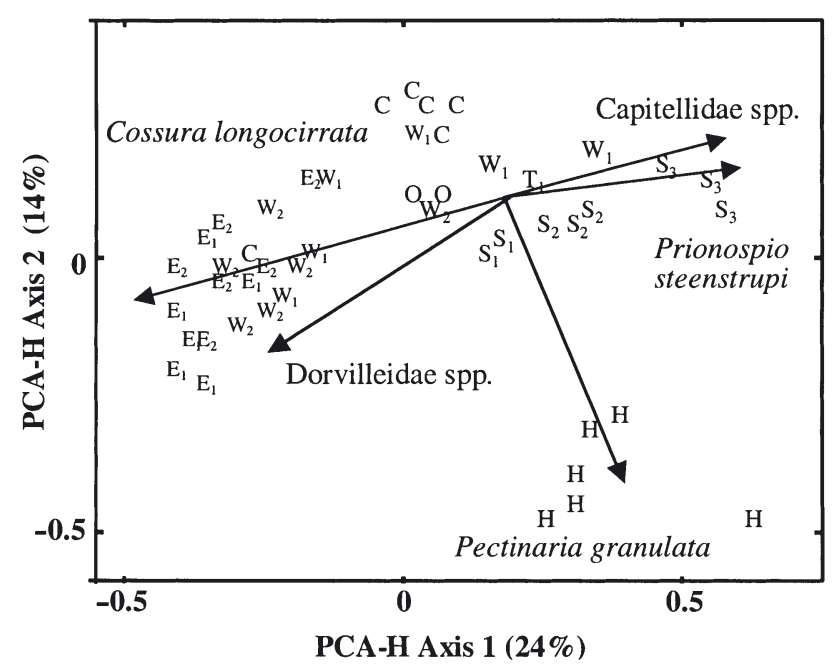

Fig. 3. PCA-H metric scaling ordination in 2 dimensions of box core spatial patterns based on CNESS ( $n=10$ individuals). The first 2 axes explain 24 and $14 \%$ of the variance in the data respectively. Species vectors (Gabriel Euclidean distance biplot) have been overlaid on community ordination to show which species contribute to CNESS variation among samples and therefore drive spatial patterns 

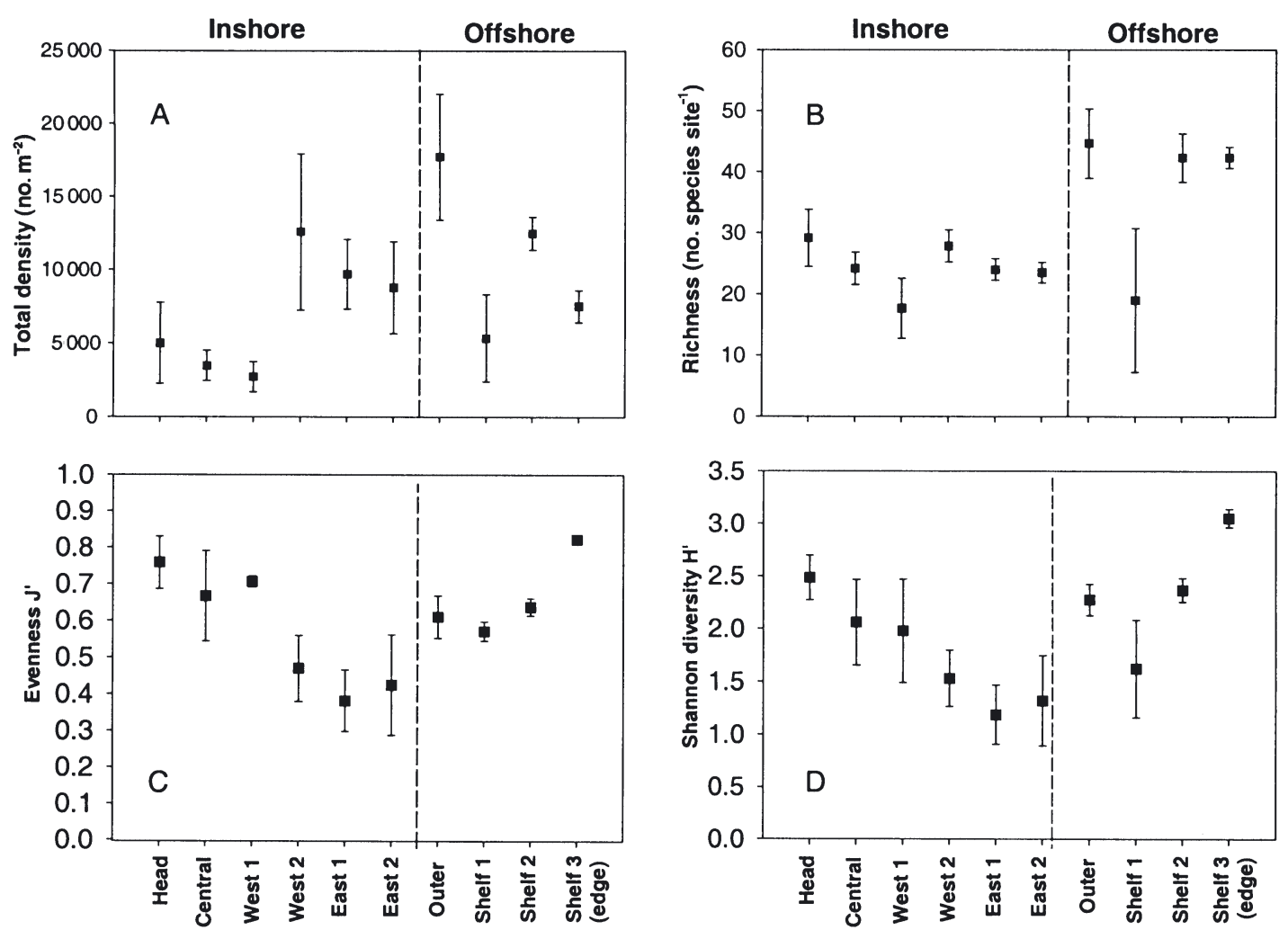

Fig. 4. Plot showing means and $95 \%$ confidence intervals for (A) total density of macrofauna at each site (n $=6$ for Head, Central, West 1 and 2, East 1 and 2, n = 2 for Shelf 1, and $\mathrm{n}=3$ for Outer, Shelf 2 and 3), (B) species richness, (C) species evenness $J^{\prime}$,

(D) Shannon diversity $H^{\prime}$. Note scale on $y$-axes differs among panels

inner bay. Analysis of finer-scale patterns within the inner bay (authors' unpubl. data) revealed spatial patterns that were not evident in this analysis of broadscale patterns. For example, discernible communities occurred at the head of the bay $(\mathrm{H})$, another grouping included samples from the Central and upper Western Channel, and a third group included samples from the Eastern and lower Western Channels.

Overall density ranged between 2717 and 17725 ind. $\mathrm{m}^{-2}$ (Fig. 4A) with highest densities in the outer bay (O) and lowest densities at the head of the bay $(\mathrm{H})$, in the Central Channel (C) and in the upper Western Channel $\left(\mathrm{W}_{1}\right)$. Despite some overlap, total density was significantly higher ( $\mathrm{n}=47$, $U$-test $=105.5, \mathrm{p}=0.020$ ) offshore $\left(\bar{x}=451.0\right.$ ind. per $\left.400 \mathrm{~cm}^{2}\right)$ than inshore $\left(\bar{x}=282.19\right.$ ind. per $\left.400 \mathrm{~cm}^{2}\right)$ (Table 1). A comparison of the distribution of macrofauna among vertical fractions revealed that the majority of individuals (>70\%) were found in the top 0 to $3 \mathrm{~cm}$ of sediment. However, significantly fewer organisms $(n=47, U$-test $=$
42.5, $\mathrm{p}=<0.001$ ) were found in the 3 to $10 \mathrm{~cm}$ portion of samples from the head and inner bay $(\bar{x}$ inshore $=$ 28.33 ind. per $400 \mathrm{~cm}^{2}$ ) than those from the outer bay and shelf $\left(\bar{x}\right.$ offshore $=104.46$ ind. per $\left.400 \mathrm{~cm}^{2}\right)($ Fig. 5, Table 1).

A total 15120 individuals were collected from 10 stations encompassing 118 different taxa. Many taxa were present at very low densities at few sites; of the 118 taxa, 35 were present at only 1 site. The dominant taxa in Placentia Bay included 11 polychaete species, the bivalve Thyasira sp., Nemertea species and the

Table 1. Mann-Whitney test for differences in diversity, species richness, evenness, total density, density in the 3 to $10 \mathrm{~cm}$ core fraction and density in the 0 to $3 \mathrm{~cm}$ core fraction between the inshore $\left(\mathrm{H}, \mathrm{C}, \mathrm{E}_{1}, \mathrm{E}_{2}, \mathrm{~W}_{1}, \mathrm{~W}_{2}\right)$ and offshore $\left(\mathrm{O}, \mathrm{S}_{1}, \mathrm{~S}_{2}, \mathrm{~S}_{3}\right)$ regions of Placentia Bay at $\alpha=0.05$. Significant $p$-values are shown in bold

\begin{tabular}{|lrccr|}
\hline Variables & $\begin{array}{r}\text { Inshore } \\
(\mathrm{n}=36)\end{array}$ & $\begin{array}{c}\text { Offshore } \\
(\mathrm{n}=11)\end{array}$ & $\begin{array}{r}\text { Mann-Whitney } U \text {-test } \\
(\mathrm{n}=47)\end{array}$ & p-value \\
\hline Diversity $H^{\prime}$ (base 2) & 1.76 & 2.39 & 95.00 & $\mathbf{0 . 0 1 0}$ \\
Species richness & 24.17 & 38.72 & 50.50 & $<\mathbf{0 . 0 0 1}$ \\
Evenness $\left(J^{\prime}\right)$ & 0.57 & 0.67 & 145.00 & 0.183 \\
Total density & 21.43 & 32.41 & 105.5 & $\mathbf{0 . 0 2 0}$ \\
$0-3 \mathrm{~cm}($ mean per $400 \mathrm{~cm})$ & 282.2 & 451.0 & 105.50 & $\mathbf{0 . 0 2 0}$ \\
$3-10 \mathrm{~cm}$ (mean per $400 \mathrm{~cm})$ & 28.33 & 104.46 & 42.50 & $<\mathbf{0 . 0 0 1}$ \\
\hline
\end{tabular}




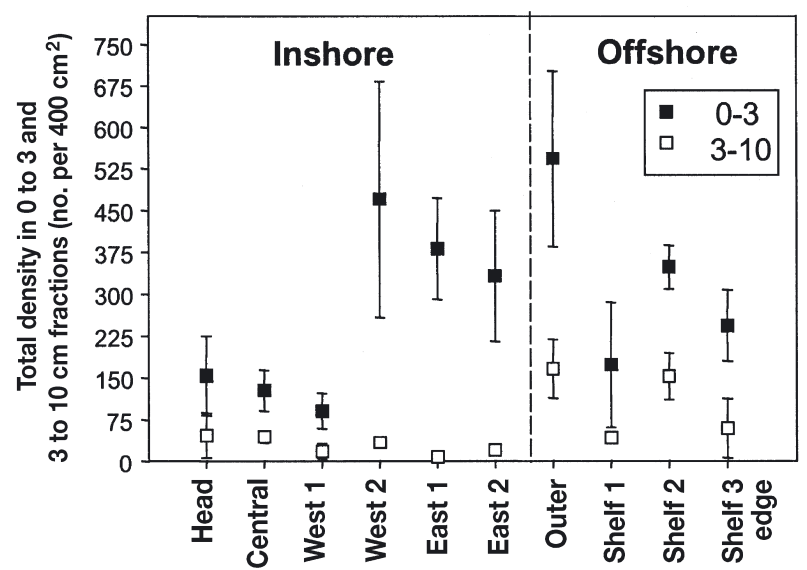

Fig. 5. Plot showing means and $95 \%$ confidence intervals for total density of macrofauna in the 0 to $3 \mathrm{~cm}$ and 3 to $10 \mathrm{~cm}$ sediment fractions at each site ( $\mathrm{n}=6$ for Head, Central, West 1 and 2, East 1 and 2, $\mathrm{n}=2$ for Shelf 1, and $\mathrm{n}=3$ for Outer, Shelf 2 and 3 )

amphipod Byblis gaimardi (Fig. 6). Polychaetes were the most abundant group, comprising $88 \%$ of total infauna. Bivalves and amphipods constituted 4 and $2 \%$, respectively. The single most abundant species was the polychaete Cossura longocirrata, which comprised $54 \%$ of the total infauna ( $63 \%$ of polychaetes); densities ranged from 33 to 350 ind. per $400 \mathrm{~cm}^{2}$ (Fig. 6). The polychaetes Prionospio steenstrupi (8\% of total infauna), Nephtys neotena (3\% of total infauna) and Dorvilleidae (3\% of total infauna), including Parougia eliasoni and Dorvillea rudolphi, were the next most abundant taxa. Gabriel biplots indicate that the polychaetes $C$. longocirrata and Dorvilleidae spp. were more abundant within the inner part of the bay $\left(\mathrm{H}, \mathrm{C}, \mathrm{W}_{1 \& 2}, \mathrm{E}_{1 \& 2}\right)$, whereas Capitellidae spp. and $P$. steenstrupi were more abundant on the shelf $\left(\mathrm{S}_{1 \& 2}\right)$ and at the shelf edge $\left(\mathrm{S}_{3}\right)$, (Fig. 6). At the head of the bay $(\mathrm{H})$, the polychaete Pectinaria granulata was abundant, comprising $25 \%$ of total densities. This species was either absent or rare at all other sites (Fig. 6).

Discriminant function analysis on the above site groupings identified 40 taxa, in addition to those listed above, as being important in the between-site variation observed in PCA-H plots. Of these 40, taxa comprising $>5 \%$ of the total density at any one site included Thyasira sp., which was abundant in the Central Channel (C) and outer bay, as well as Nemertea, Paraonidae sp., Chaetozone setosa and Terebellides stroemi, which were also more abundant at the shelf edge.

Species richness ranged from 18 to 45 taxa per sample (Fig. 4B) and was significantly higher ( $\mathrm{n}=47$, $U$-test $=50.5, \mathrm{p}<0.001)$ in offshore $(\bar{X}$ offshore $=38.72$, $\bar{X}$ inshore $=24.17)$ samples $($ Table 1$)$; however, species
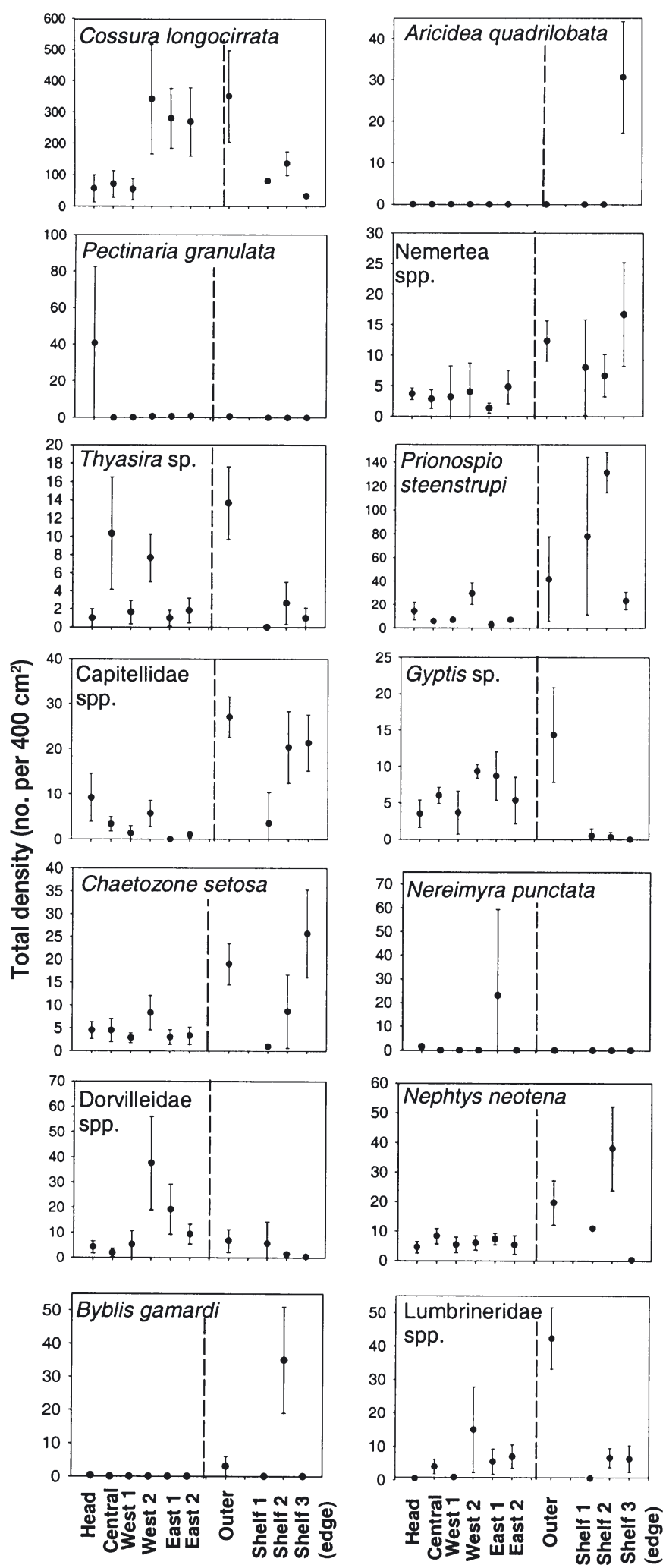

Fig. 6. Plot showing mean densities and $95 \%$ confidence intervals of dominant taxa with $\mathrm{n}=6$ (Head, Central, West 1 and 2, East 1 and 2), $\mathrm{n}=2$ (Shelf 1 ) and $\mathrm{n}=3$ (Outer, Shelf 2 and 3). Note scale on $y$-axes differs among taxa 
richness offshore was highly variable. Evenness varied between 0.42 and 0.82 (Fig. 4C) and was not significantly different $(\mathrm{n}=47, U$-test $=145.0, \mathrm{p}=0.018)$ between inshore and offshore stations ( $\bar{x}$ offshore $=$ $0.67, \bar{x}$ inshore $=0.57$ ) (Table 1$)$. Shannon diversity $H^{\prime}$ indices for Placentia Bay and the adjacent shelf (Fig. 4D) ranged from very low to moderate (1.3 to 3.1). Diversity $H^{\prime}$ was lowest in the Eastern Channel $\left(\mathrm{E}_{1 \& 2}\right)$, lower Western Channel $\left(\mathrm{W}_{1}\right)$ and $\mathrm{S}_{1}$, and was highest at the shelf edge $\left(\mathrm{S}_{3}\right)$. Diversity inshore $(\bar{x}=1.76)$ was significantly lower $(\mathrm{n}=47, U$-test $=33.6, \mathrm{p}<0.010)$ than offshore $(\bar{x}=2.39)$ (Table 1$)$.

\section{Environmental data}

Mean sedimentary organic carbon in the bay was significantly higher $(\mathrm{n}=43, U$-test $=15$, $\mathrm{p}<0.001)$ in the head and inner bay $(\bar{x}=6.49 \%$, $\mathrm{SD}=1.20, \mathrm{n}=18$ ) compared to the outer bay $(\mathrm{O})$, shelf $\left(\mathrm{S}_{1}, \mathrm{~S}_{2}\right)$ and shelf edge $\left(\mathrm{S}_{3}\right) ;(\bar{x}=2.25 \%$, $\mathrm{SD}=1.65, \mathrm{n}=10) . \mathrm{C} / \mathrm{N}$ ratios were relatively low in the area between the head of the bay and shelf $(\bar{x}=8.63, \mathrm{SD}=0.40, \mathrm{n}=26)$, and were much higher at the shelf edge $(\bar{x}=19.4, \mathrm{SD}=19.44$, $\mathrm{n}=2$ ) (Table 2). The head and inner bay were dominated by clay and very fine to medium silt sized sediment particles, whereas the outer bay and shelf edge contained more coarse silt and very fine sand (Table 2). Mixed-layer temperatures averaged $9.33^{\circ} \mathrm{C}(\mathrm{SD}=0.55, \mathrm{n}=6)$ in the head and inner bay and $6.82^{\circ} \mathrm{C}(\mathrm{SD}=1.21, \mathrm{n}=6)$ in the outer bay, shelf and shelf edge. Bottom temperatures in the inner bay were low $(\bar{x}=$ $-0.54^{\circ} \mathrm{C}, \mathrm{SD}=0.23, \mathrm{n}=5$ ), except at the head of the bay, where temperature was $3.43^{\circ} \mathrm{C}$. Average outer-bay and shelf-bottom temperatures were $-0.50^{\circ} \mathrm{C}(\mathrm{SD}=0.12, \mathrm{n}=5)$, but temperature was much higher at the shelf edge $\left(7.0^{\circ} \mathrm{C}\right)$ (Table 3). Chl a concentrations in the water were high at the head and inner bay during June $\left(\bar{x}=0.50 \mu g 1^{-1}, \mathrm{SD}=0.39, \mathrm{n}=6\right)$ and August $\left(\bar{x}=0.48 \mu \mathrm{g} \mathrm{l}^{-1}, \mathrm{SD}=0.22, \mathrm{n}=6\right)$ (Table 3) (see Bradbury et al. 2000 for chl a field data maps).

Spatial pattern in PCA analysis of environmental data showed similar spatial groupings to those observed for the species data. The head and inner bay samples clearly separated from outer bay and shelf samples, along Factor 1, whereas the shelf edge samples were separated from the outer bay and remaining shelf samples along Factor 2 (Fig. 7). The head of the bay also differed from the inner bay samples. Unlike the PCA-H analysis of species data, the centre bay grouped with the rest of the inner bay. Produc- tion-related variables (average \% C, chl a July and August, average \% N), abiotic water column variables (mixed-layer temperature) and grain size (very fine to medium silt) were heavily weighted positive loadings along Factor 1. Very fine sand and abiotic water column variables (mixed layer salinity, bottom temperature) and distance from the head of the bay and shoreline were negative loadings along Factor 1. Bottom temperature was heavily weighted positively along Factor 2. Chl a (April, July and August) was significantly correlated positively with sedimentary organic carbon. Mixed-layer temperature was also significantly correlated with chl a (April and July) and organic carbon. Multiple regression analysis showed that all of the models developed to predict infaunal density, species richness and diversity were signifi-
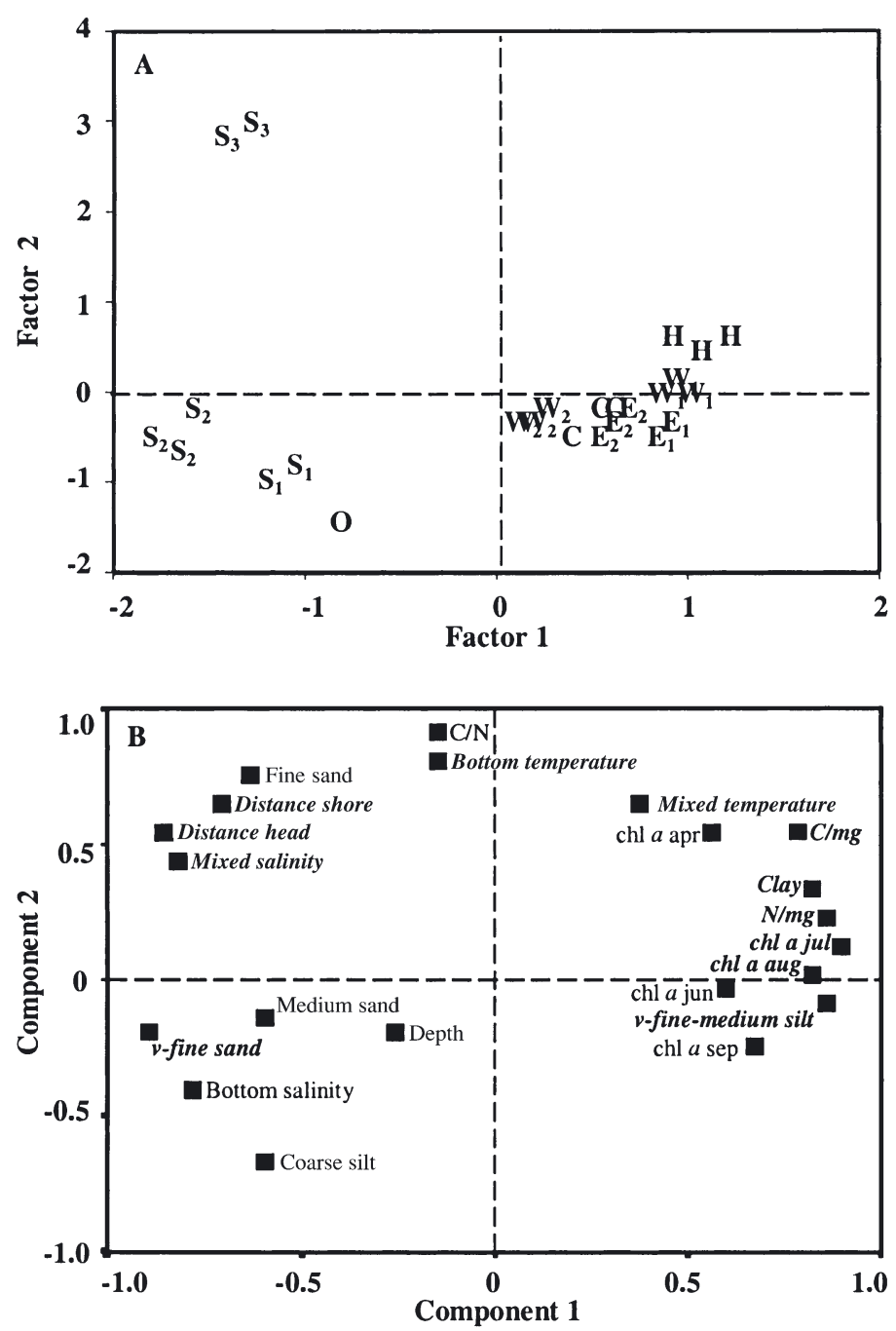

Fig. 7. (A) Spatial patterns defined by principal components analysis of environmental variables. (B) Heavily weighted loadings $( \pm 0.70)$ are shown in bold and italics 


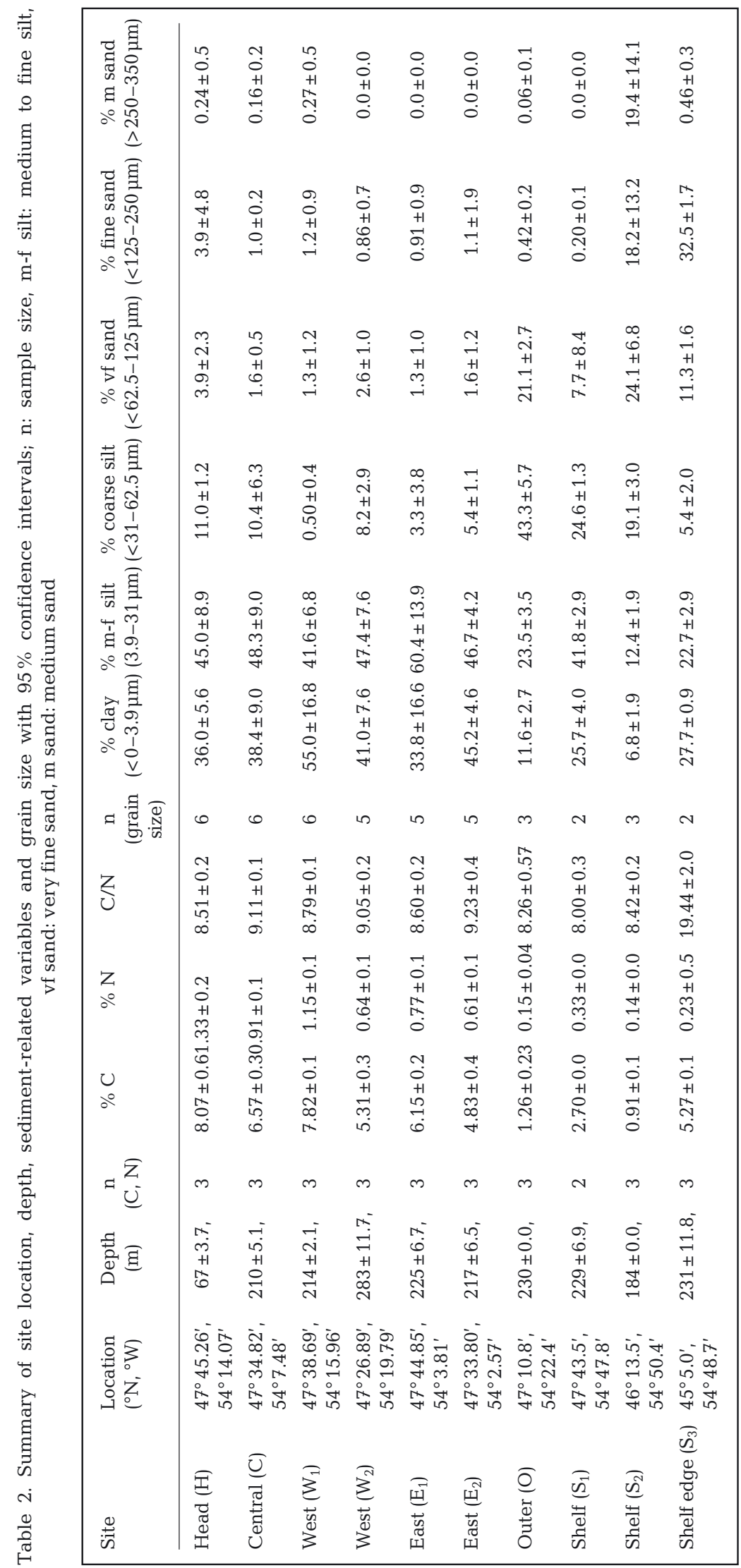

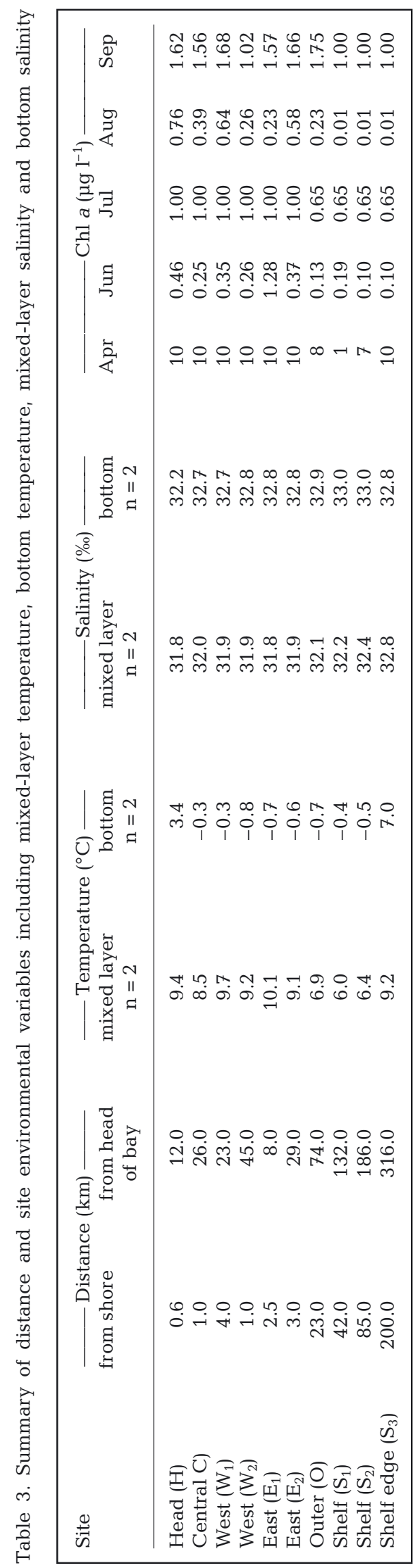


Table 4. (A) Multiple stepwise regression of environmental variables with density (no. $\mathrm{m}^{-2}$ ). The overall model is significant $\left(\mathrm{p}=0.009, \mathrm{R}^{2}=0.71\right.$ ) with $\mathrm{df}=9,24$ (regression and total, respectively) and $F=3.99$. (B) Multiple stepwise regression of environmental variables with species richness. The overall model is significant $\left(p=0.001, R^{2}=0.79\right)$ with $\mathrm{df}=9,24$ (regression and total, respectively) and $F=6.43$. Environmental variable(s) that contributed significantly to the model are shown in bold

\begin{tabular}{|lcc|}
\hline $\begin{array}{l}\text { Environmental } \\
\text { variables }\end{array}$ & $\begin{array}{c}\text { Standardized regres- } \\
\text { sion coefficients }\end{array}$ & $\mathrm{p}$-values \\
\hline (A) & & \\
Very fine to medium silt & 0.176 & 0.599 \\
Depth & 0.727 & 0.188 \\
Salinity (mixed layer) & 0.921 & 0.686 \\
Temperature (mixed layer) & 0.909 & 0.109 \\
Temperature (bottom) & -0.798 & 0.359 \\
Salinity (bottom) & -1.494 & 0.221 \\
Distance from head of bay & -0.160 & 0.934 \\
Chl a Jun & -0.146 & 0.662 \\
\% carbon & -1.770 & $\mathbf{0 . 0 0 5}$ \\
& & \\
(B) & & \\
Very fine to medium silt & 0.032 & 0.907 \\
Depth & -1.590 & 0.558 \\
Salinity (mixed layer) & 0.265 & $\mathbf{0 . 0 2 7}$ \\
Temperature (mixed layer) & 1.319 & $\mathbf{0 . 0 1 0}$ \\
Temperature (bottom) & 4.587 & 0.064 \\
Salinity (bottom) & -1.412 & 0.065 \\
Distance from head of bay & -1.949 & 0.131 \\
Chl a Jun & -2.517 & 0.847 \\
\% carbon & 0.054 & $\mathbf{0 . 0 0 3}$ \\
& & \\
\hline
\end{tabular}

cant. Sedimentary organic carbon was the only significant predictor of infaunal density with a negative relationship (Table 4A). Mixed-layer temperature and salinity were significant positive predictors of species richness (Table 4B). Organic carbon was also negatively related to species richness. No single environmental variable predicted Shannon diversity (i.e. no significant simple linear regressions).

\section{DISCUSSION}

Although benthic ecologists have long appreciated that marine sedimentary communities are patchily distributed (Petersen 1913, Jones 1950), the question of why spatial variation exists is still not fully understood. This is the first comprehensive study on sedimentary macrofauna in muddy substrates in Placentia Bay, Newfoundland, and the adjacent shelf environment, and it suggests that broad-scale changes in community composition may be related to surface water characteristics (e.g. chl a).

Sedimentary organic carbon may help to explain some of the faunal variation, in that high amounts of organic carbon within Placentia Bay sediments influ- enced species composition, richness and diversity of macrofaunal communities. Many of the dominant species in Placentia Bay are typically abundant in organicrich areas. For example, in a shallow site $(46 \mathrm{~m})$ in St. Margaret's Bay, Nova Scotia (Volckaert 1987), where organic carbon content in sediments (3.8 to $4.6 \%$ ) rivalled that of Placentia Bay, dominant species were similar to those in Placentia Bay. In contrast, organic carbon in nearby Conception Bay was much lower (0.58 to $2.52 \%$ ) (Kennedy 1985) than in Placentia Bay, and 2 of the 3 dominant taxa in Conception Bay that were not encountered in Placentia Bay are sensitive to organic pollution (Mirza \& Gray 1981: Maldane sarsi; Pearson et al. 1983: Nepthys incisa). Macrofaunal densities inshore (2717 to 12600 ind. $\mathrm{m}^{-2}$ ) were high compared to other muddy, northern areas at similar depths. Long \& Lewis (1987) found macrofaunal densities in the Gulf of St. Lawrence to be very low (330 to 3425 ind. $\mathrm{m}^{-2}, 0.5 \mathrm{~mm}$ sieve) and densities were 20 to 37 times higher in Placentia Bay compared to deep (207 to $274 \mathrm{~m}$ ), muddy areas of Conception Bay (134.8 to 380.8 ind. $\mathrm{m}^{-2}, 1 \mathrm{~mm}$ sieve: Schiebe 1991); however, a coarser sieve size in this study $(1 \mathrm{~mm})$ was also likely a contributing factor. In contrast, macrofaunal densities in Nain Bay, Labrador (7050 to 17198 ind. $\mathrm{m}^{-2}$, sieve size not reported: Mills 1975), correspond to some of the higher densities observed in Placentia Bay. High densities of macrofauna in Placentia Bay were not unexpected, given that the bay is relatively productive.

At a continental slope site (530 to $2003 \mathrm{~m}$ deep) off Cape Hatteras, North Carolina, where there is a high flux of organic carbon, infaunal assemblages were also strikingly different from adjacent regions (Blake \& Hilbig 1994). The polychaete Cossura longocirrata was one of the dominant species, and infaunal assemblages were characterised by lower species richness and diversity (Blake et al. 1987, Blake \& Grassle 1994). Levels of diversity within the inshore portion of Placentia Bay were low, largely because of the dominance of C. longocirrata; this species has been described as opportunistic (Olsgard \& Hasle 1993). In Placentia Bay, lower organic carbon offshore corresponded to higher species richness, diversity and lower densities of $C$. longocirrata. Species diversity $\left(H^{\prime}\right)$ and richness were also relatively higher in Conception Bay $\left(H^{\prime}: 2.2\right.$ to 3.0; richness: 22 to 46) compared to Placentia Bay (Scheibe 1991); however, these comparisons should be interpreted with caution given the differences in collection and processing techniques.

Distinct communities occurred at the head of the Bay, in the Central Channel and on the continental shelf. Sites within the Eastern and Western Channels were generally similar to one another, whereas those from the outer bay to the edge of the continental shelf changed with increased distance from the inner bay. 
This pattern suggests that the islands located within the inner portion of Placentia Bay may directly or indirectly play a delimiting role for environmental and biological parameters. The first PCA-H axis suggests an inshore/offshore trend in community differences, whereas the second axis describes inner bay community differences. In general, the inshore (head and inner bay) portion of the bay was characterised by greater mixed-layer temperatures, higher surface production (chl a), large amounts of relatively fresh organic carbon (low $\mathrm{C} / \mathrm{N}$ ratios) and high densities of Cossura longocirrata.

At local scales (e.g. head of the bay and offshore), grain size was particularly important in influencing macrofaunal composition, despite varying amounts of organic carbon. Pectinaria granulata was a dominant member of the infaunal community at the shallow site at the head of the bay, where sediments contained more fine sand compared to other inshore sites. P. granulata displays remarkable selectivity in grain size when tube building (P. Pocklington pers. obs.) and the relatively higher variability in fine sand deposits at this site may explain variability in abundance. Five polychaete species (Scoloplos armiger, Pherusa plumosa, Spio filicornis, Syllides longocirrata and Goniada maculata) were shared between the head of the bay and the offshore sites, but were effectively absent in areas in between. All of these species are usually found in coarse sediments (Hughes et al. 1972, Appy et al. 1980, P. Pocklington pers. obs.), and offshore sites did contain high proportions of coarse and medium sand. Snelgrove \& Butman (1994) have argued that sediment grain size may often be a surrogate for correlated variables such as larval supply. In this system, however, the spatial discontinuity suggests that grain size per se may be important, rather than organic content or larval supply. Indeed, the strong cyclonic surface currents in Placentia Bay (Schillinger et al. 2000) provides ample opportunity for dispersal throughout the bay. One other contributing factor to the composition of the shelf edge community may have been the influence of the Gulf Stream (Sheng \& Thompson 1996). Aricidea quadrilobata was only found at the shelf edge, where bottom temperature was higher than in any other area; Placentia Bay is near its northern limit (P. Pocklington unpubl. data).

The offshore sites appear to support a deeper-living fauna, where significantly more organisms were found in the 3 to $10 \mathrm{~cm}$ core fraction compared to inshore. Inshore areas may have reduced oxygen concentrations below the first few millimetres of sediment, given that sedimentary organic carbon content inshore was very high (4.8 to $9.1 \%)$. Valderhaug \& Gray (1984) reported that carbon levels comparable to those observed in Placentia Bay are typical for areas that receive high sewage input. High organic carbon degradation in sed- iments is associated with reduced porewater oxygen content and accumulation of hydrogen sulphide. Both variables limit infaunal abundance (Lopez-Jumar 1981, Levin et al. 1991). Placentia Bay inshore cores smelled strongly of hydrogen sulphide and were noticeably black below the top 2.0 to $2.5 \mathrm{~cm}_{\text {; }}$ however, black sediment was not observed until much deeper in offshore sediments. High amounts of organic carbon in Placentia Bay sediments may be a result of high rates of sedimentation or slowed degradation of organic material due to cold temperatures (Pomeroy \& Deibel 1986). Although there are small coastal communities around Placentia Bay, it is unlikely that sewage runoff is a significant factor for such a large, well-flushed bay.

Low C/N ratios for Placentia Bay indicate that relatively fresh (Banse 1974) and easily degradable (Parsons et al. 1977) organic material from the plankton reaches the benthos; $\mathrm{C} / \mathrm{N}$ ratios indicate food quality in the benthic environment (Mills 1975, Grebmeier et al. 1988, Levin et al. 1991). Much higher ratios (e.g. 14 to 30) are expected for lower-quality refractory material typical of terrestrial sources (Godell 1972). Freshwater sources entering Placentia Bay are few, and supply of allochthonous particulate material is likely of little influence. Nonetheless, there was terrestrial debris in cores collected at the head of the bay (authors' pers. obs.). Low $\mathrm{C} / \mathrm{N}$ ratios along with the association between areas with high surface chl $a$ and sedimentary organic carbon suggest that water column production sinks fairly quickly to the bottom (e.g. Ambrose \& Renaud 1995) before it degrades or is advected out of the bay.

Studies at scales larger than Placentia Bay have shown a positive relationship between surface chl $a$ concentrations and benthic biomass and/or abundance (Grebmeier et al. 1988, Ambrose \& Renaud 1995), but a negative relationship was observed in Placentia Bay. Similarly, the relationship between total macrofaunal density and sedimentary organic carbon was negative (Table 3). Abundance was significantly higher in the less productive offshore sites, and within the inshore sites some of the lowest densities were found at the head of the bay. Ambrose \& Renaud (1995) noted some decoupling of surface production and benthic biomass in a Greenland polynya, where benthic biomass/density was lower than in areas where surface and sedimentary chl a were closely linked; decoupling was attributed to zooplankton grazing. Decoupling was probably not the mechanism in Placentia Bay because high surface chl a was generally associated with high sedimentary organic carbon.

The negative relationship between surface production and infaunal density in Placentia Bay is likely a result of several confounding factors. Offshore densities were greatly increased by the deeper-living fauna; if only the upper 0 to $3 \mathrm{~cm}$ core fractions are compared, 
then inshore and offshore densities are not significantly different $(\mathrm{n}=47, U$-test $=124.5, \mathrm{p}=0.065)$. Moreover, a single offshore site located near Oderin Bank (Fig. 1) is known by local fishermen to be very productive, and had much higher densities than other offshore sites. Upwelling areas have been associated with high macrofaunal abundance (Levin \& Gage 1998), except when hypoxia confounds the pattern (Sanders 1969). Inshore, low densities were observed at 3 sites where organic carbon was highest; low densities may be a result of sulphide production in sediments or poorer food quality. In conclusion, broadscale patterns of community composition and density in Placentia Bay and the adjacent shelf are largely correlated with surface oceanography as seen by the importance of surface characteristics (chl a) and sedimentary carbon (which tracks surface production).

Acknowledgements. We are grateful to the crew of the MV 'Mares' and to J. Martin, T. Brown, B. Nolan and A. Beaudoin for assistance in the field. Taxonomic assistance was provided by P. Pocklington, R. Petrecca, D. Steele, J. P. Grassle and K. Gilkinson. Discussions and input from R. Haedrich and D. Schneider helped in the design of the study; they also provided valuable comments on an earlier draft of this manuscript, as did W. Ambrose, D. Deibel and J. P. Grassle. Additional comments from L. Levin and 3 anonymous reviewers were also extremely helpful. This research was supported by a Natural Sciences and Engineering Research Council of Canada (NSERC) Research Grant to P.V.R.S., the NSERC Industrial Chair in Fisheries Conservation, and a fellowship to P.A.R. from the School of Graduate Studies at Memorial University.

\section{LITERATURE CITED}

Ambrose WG Jr, Renaud PE (1995) Benthic response to water column productivity patterns: evidence for benthicpelagic coupling in Northeast water polynya. J Geophys Res 100:4411-4421

Appy TD, Linkletter EL, Dadswell MJ (1980) A guide to the marine flora and fauna of the bay of fundy: Annelida: Polychaeta. Fish Mar Serv Tech Rep 920:1-123

Banse A (1974) On the interpretation of data for carbon to nitrogen ratio of phytoplankton. Limnol Oceanogr 19:695-699

Blake JA, Grassle JF (1994) Benthic community structure on the U.S. South Atlantic slope off the Carolinas: spatial heterogeneity in a current-dominated system. Deep-Sea Res II 4-6:835-874

Blake JA, Hilbig B (1994) Dense infaunal assemblages on the continental slope off Cape Hatteras, North Carolina. Deep-Sea Res II 4-6:875-899

Blake JA, Hecker B, Grassle JF, Brown B and 9 others (1987) Study of biological processes on the US South Atlantic slope and rise: Phase 2. Final Report Prepared for the US Department of the Interior, Minerals Management Service, Washington, DC, p 1-415

Bradbury IR, Snelgrove PVR (2001) Contrasting larval transport in demersal fish and benthic invertebrates: the roles of behavior and advective processes in determining spatial pattern. Can J Fish Aquat Sci 58:811-823

Bradbury IR, Snelgrove PVR, Fraser S (2000) Transport and de- velopment of eggs and larvae of Atlantic cod, Gadus morhua, in relation to spawning time and location in coastal Newfoundland. Can J Fish Aquat Sci 57:1761-1772

Butman CA (1987) Larval settlement of soft-sediment invertebrates: the spatial scales of pattern explained by active habitat selection and the emerging role of hydrodynamical processes. Oceanogr Mar Biol Annu Rev 25:113-165

Davis JM, Payne P (1984) Supply of organic matter to the sediment in northern North Sea during a spring phytoplankton bloom. Mar Biol 78:315-324

Drazen JC, Baldwin RJ, Smith KL Jr (1998) Sediment community response to a temporally varying food supply at an abyssal station in the NE pacific. Deep-Sea Res II 45: 893-913

Duineveld GCA, Tselepides A, Witbaard R, Bak RPM, Berghuis EM, Nieuwland G, Weele J van der, Kok A (2000) Benthic-pelagic coupling in the oligotrophic Cretan Sea. Prog Oceanogr 46:457-480

Elmgren RA (1978) Structure and dynamics of Baltic benthic communities, with particular reference of the relationship between macro- and meio-fauna. Kiel Meeresforsch Sonderh 4:1-22

Gabriel KR (1971) The biplot graphic display of matrices with application to principal component analysis. Biometrika 58:453-467

Godell HG (1972) Carbon/nitrogen ratio. In: Fairbridge RW (ed) Encyclopedia of geochemistry and environmental science. Van Nostrand Reinhold, New York

Gooday AJ, Pfannkuche O, Lambshead PJD (1996) An apparent lack of response by metazoan meiofauna to phytodetritus deposition in the bathyal north-eastern Atlantic. J Mar Biol Assoc UK 76:297-310

Grassle JF, Smith W (1976) A similarity measure sensitive to the contribution of rare species and its use in investigation of variation in marine benthic communities. Oecologia 25: $13-22$

Gray JS (1974) Animal-sediment relationships. Oceanogr Mar Biol Annu Rev 12:223-261

Grebmeier JM, McRoy CP, Feder HM (1988) Pelagic-benthic coupling on the shelf of the northern Bering and Chukchi Seas. I. Food supply source and benthic biomass. Mar Ecol Prog Ser 48:57-67

Houston KA, Haedrich RL (1984) Abundance and biomass of macrobenthos in the vicinity of Carson Submarine Canyon, northwest Atlantic Ocean. Mar Biol 82:301-305

Hughes RN, Peer DL, Mann KH (1972) Use of multivariate analysis to identify functional components of the benthos in St. Margaret's Bay, Nova Scotia. Limnol Oceanogr 17: $111-121$

Jones NS (1950) Marine bottom communities. Biol Rev 25: 283-313

Jørgensen BB (1983) Processes at the sediment-water interface. In: Bolin B, Cook RB (ed) The major biogeochemical cycles and their interactions. Stockholm Scientific Committee on Problems of the Environment, Stockholm, p 477-509

Kennedy VS (1985) A summer benthic survey in Conception Bay, Newfoundland, emphasizing zoogeography of annelids and amphipods. Can J Zool 63:1863-1869

Lampitt RS, Raine RCT, Billett DSM, Rice AL (1995) Material supply to the European continental slope: a budget based on benthic oxygen demand and organic supply. Deep-Sea Res I 42:1865-1880

Lawson GL, Rose G (2000) Small-scale spatial and temporal patterns in spawning of Atlantic cod (Gadus morhua) in coastal Newfoundland waters. Can J Fish Aquat Sci 57:1011-1024

Lewis DW, McConchie D (1994) Analytical sedimentology. Chapman \& Hall, New York 
Levin AL, Gage JD (1998) Relationships between oxygen, organic matter and the diversity of bathyal macrofauna. Deep-Sea Res II 45:129-163

Levin LA, Huggett CL, Wishner KF (1991) Control of deep-sea benthic community structure by oxygen and organicmatter gradients in the eastern Pacific Ocean. J Mar Res 49:763-800

Lobel PS, Robinson AR (1986) Transport and entrapment of fish larvae by ocean mesoscale eddies and current in Hawaiian waters. Deep-Sea Res 33:483-500

Lochte K, Turley CM (1988) Bacteria and cyanobacteria associated with phytodetritus in the deep sea. Nature 333:67-69

Long B, Lewis JB (1987) Distribution and community structure of the benthic fauna of the north shore of the Gulf of St. Lawrence described by numerical methods of classification and ordination. Mar Biol 95:93-101

Longhurst A (1998) Ecological geography of the sea. Academic Press, San Diego

Lopez-Jumar E (1981) Spatial distribution of the infaunal benthic communities of the Ria de Muros, north-west Spain. Mar Biol 63:29-37

Mills EL (1975) Benthic organisms and structure of marine ecosystems. J Fish Res Board Can 32:1657-1663

Mirza FB, Gray JS (1981) The fauna of benthic sediments from the organically enriched Oslofjord, Norway. J Exp Mar Biol Ecol 54:181-207

Morrisey DJ, Howitt L, Underwood AJ, Stark JS (1992) Spatial variation in soft-sediment benthos. Mar Ecol Prog Ser 81: 197-204

Ólafsson EB, Peterson CH, Ambrose WG Jr (1994) Does recruitment limitation structure populations and communities of macro-invertebrates in marine soft sediments: the relative significance of pre- and post-settlement processes. Oceanogr Mar Biol Annu Rev 32:65-110

Olsgard F, Hasle JR (1993) Impact of waste from titanium mining on benthic fauna. J Exp Mar Biol Ecol 172:185-213

Orloci L (1978) Multivariate analysis in vegetation research, 2nd edn. W. Junk, The Hague

Parsons TRK, Takahashi M, Hargrave BT (1977) Biological oceanographic processes, 2nd edn. Pergamon Press, Oxford

Pearson TH, Gray JS, Johannessen PJ (1983) Objective selection of sensitive species indicative of pollution-induced changes in benthic communities: data analyses. Mar Ecol Prog Ser 12:237-255

Petersen CGJ (1913) Valuation of the sea. II. The animal communities of the sea-bottom and their importance for marine zoogeography. Rep Danish Biol Stat 21:1-44

Peterson CH (1977) Competitive organization of the softbottom macrobenthic communities of southern California lagoons. Mar Biol 43:343-359

Peterson CH (1979) Predation, competitive exclusion, and diversity in the soft-sediment benthic communities of estuaries and lagoons. In: Livingston RJ (ed) Ecological processes in coastal and marine systems. Plenum Press, New York, p 233-264

Pfannkuche O (1993) Benthic response to the sedimentation of particulate organic matter at the BIOTRANS station, $47^{\circ} \mathrm{N} 20^{\circ} \mathrm{W}$. Deep-Sea Res II 40:135-149

Pomeroy LR, Deibel D (1986) Temperature regulation of bacterial activity during the spring bloom in Newfoundland coastal waters. Science 233:359-361

Rhoads DC (1974) Organism-sediment relations on the muddy sea floor. Oceanogr Mar Biol Annu Rev 12: 263-300

Rhoads DC, Young DK (1970) The influence of deposit- feeding organisms on sediment stability and community trophic structure. J Mar Res 28:150-178

Sanders HL (1969) Marine benthic diversity and the stabilitytime hypothesis. Brookhaven Symp Biol 22:71-80

Scheibe S (1991) The benthic macrofauna of the deep sublitoral in Conception Bay, Newfoundland, Canada. MSc thesis, Memorial University of Newfoundland, St. John's

Schillinger DJ, Simmons P, deYoung B (2000) Analysis of the mean circulation pattern in Placentia Bay: Spring and summer 1999. Physics and physical oceanography data report 2000-1. Memorial University of Newfoundland, St. John's

Shanks A (1995) Mechanisms of cross-shelf dispersal of larval invertebrates and fish. In: McEdward L (ed) Ecology of marine invertebrate larvae. CRC Press, New York

Sheng J, Thompson RK (1996) Summer circulation on the Newfoundland shelf and the Grand Banks: the roles of local density gradients and remote forcing. Atmos-Ocean 34:257-284

Smetacek V (1984) The supply of food to the benthos. In: Fasham MJ (ed) Flows of energy and materials in marine ecosystems: theory and practice. Plenum Press, New York, p $517-547$

Smith KL Jr, Laver MB, Brown NO (1983) Sediment community oxygen consumption and nutrient exchange in the central and eastern North Pacific. Limnol Oceanogr 25: 882-898

Snelgrove PVR, Butman CA (1994) Animal-sediment relationships revisited: cause versus effect. Oceanogr Mar Biol Annu Rev 32:111-177

Snelgrove PVR, Austen GB, Heip C, Hutchings PA, King GM, Koike I, Lambshead PJD, Smith CR (2000) Linking biodiversity above and below the marine sediment water interface. BioScience 50:1076-1088

Snelgrove PVR, Grassle JF, Grassle JP, Petrecca R, Stocks KI (2001) The role of colonization in establishing patterns of community composition and diversity in shallow-water sedimentary communities. J Mar Res 59:813-831

Tremblay MJ, Loder JW, Werner FE, Naimie CE, Page FH, Sinclair MM (1994) Drift of sea scallop larvae Placopecten magellanicus on Georges Bank: a model study of the roles of mean advection, larval behavior and larval origin. Deep-Sea Res II 41:7-49

Trueblood DD, Gallagher ED, Gould DM (1994) Three stages of seasonal succession on the Savin Hill Cove mudflat, Boston Harbor. Limnol Oceanogr 39:1440-1454

Valderhaug VA, Gray JS (1984) Stable macrofauna community structure despite fluctuating food supply in subtidal soft sediments of Oslofjord, Norway. Mar Biol 82:307-322

Volckaert F (1987) Spatial pattern of soft-bottom Polychaeta off Nova Scotia, Canada. Mar Biol 93:627-639

Walsh, JJ, Wirick CD, Pietrafesa LJ, Whitledge TE, Hoge FE, Swift RN (1988) High-frequency sampling of the 1984 spring bloom within the Mid-Atlantic Bight: synoptic shipboard, aircraft, and in situ perspectives of the SEEP-I Experiment. Cont Shelf Res 8:529-563

Whitlatch RB (1980) Patterns of resource utilization and coexistence in marine intertidal deposit-feeding communities. J Mar Res 38:743-765

Witbaard R, Duineveld GCA, Weele Van der, Berghuis EM, Reyss JP (2000) The benthic response to seasonal deposition of phytopigments at the Porcupine Abyssal Plain in the North East Atlantic. J Sea Res 43:15-31

Woodin SA (1978) Refuges, disturbance, and community structure: a marine soft-bottom example. Ecology 59: $274-284$

Submitted: July 10, 2002; Accepted: July 3, 2003

Proofs received from author(s): October 15, 2003 
